\title{
ANALYSIS OF TECHNOLOGIES FOR PRODUCING COMPOSITES WITH POLYESTER-GLASS RECYCLATE
}

\section{Katarzyna Panasiuk}

Gdynia Maritime University, Faculty of Marine Engineering, Department of Engineering Sciences, Morska 81-87 Str., 81-225 Gdynia, Poland; e-mail: k.panasiuk@wm.am.gdynia.pl

\begin{abstract}
The aim of the article was to present selected methods for the production of layered composites in the aspect of the additive in the form of polyester-glass recyclate. The polyester-glass recyclate was obtained from the original composite material from which the ship's hull was made in Poland in the 1980s. The article presents the technology of processing polyester-glass waste in order to obtain recyclate. The methods of manual lamination, vacuum bag method and vacuum infusion were described successively. The advantages and disadvantages of particular technologies have been presented in terms of the possibility of their use in the production of polyester-glass recycled composites. From the described and verified technologies, the vacuum bag method can be the most advantageous for composites with recyclate.
\end{abstract}

Key words:

composites, manual lamination, vacuum bag method, vacuum infusion.

Research article

(C) 2018 Katarzyna Panasiuk This is an open access article licensed under the Creative Commons Attribution-NonCommercial-NoDerivatives 4.0 license (http://creativecommons.org/licenses/by-nc-nd/4.0/) 


\section{INTRODUCTION}

In Poland and in the world, the number of post-production and post-use waste increases with the products made of polyester-glass composites. Glass-fiber reinforced polyester laminates serve as structural material in shipbuilding (e.g. hulls of vessels, superstructures), in railways, automotive (e.g. car body and interior elements, train roofs, cisterns) or aviation (e.g. aircraft hulls, tanks fuel, end of beaks and ballasts), which further increases the number of waste. The wide use of these materials in the economy makes it necessary to develop appropriate methods for the utilization of both types of waste. There are many methods for recovering glass fibers from waste, which can then be used as full-value components, substituting some of the reinforcement phase in new composites with waste $[4,8]$. Continuous progress in the recycling of composites, materials that in the past were considered unfit for re-use, encourages the search for ever new, more perfect methods of waste management.

The production of plastics increases with GDP. More sustainable composite production models and better waste management - in particular higher recycling rates - offer great resource saving potential. At the same time, they would help in reducing the transport of raw materials as well as greenhouse gas emissions. The resource savings can be significant. Plastics are produced almost exclusively from crude oil and currently their production accounts for $8 \%$ of world oil production, of which $4 \%$ is used as raw material, and $3-4 \%$ as energy for manufacturing processes [1]. Research shows that recycling plastics and saving materials affect the impact of climate change, reducing abiotic resources and eco-toxicity of freshwater. Increasing the material efficiency for composites would have the greatest contribution to reducing environmental impact [15].

The technology of composite production with the addition of polyester and glass recyclate is not a matter of course. The use of recyclate as part of the reinforcing phase has an impact on the manufacturing process. The variety of methods used to make composites, as well as research to develop new composite materials may contribute to the fact that in the future most of the so-called traditional materials in industry, construction, sports or everyday life will be replaced by composites.

Taking into account the mechanization of manufacturing processes, efforts are being made to use more and more modern methods. This article presents the method of preparing polyester and glass recyclate, as well as technologies for the production of composites with its addition. 


\section{PREPARATION OF POLYESTER-GLASS RECYCLATE}

The composite material from which the ship's hull was made in Poland in the 1980s, obtained a fragment of polyester-glass scrap. It was a technological waste obtained during cutting out openings for new equipment on the unit. The scrap was pre-crushed with a hammer and then crumbled on a specially prepared station (fig. 1) for processing plastic waste (the so-called crusher). After crushing, the waste was sieved on a sieve with a sieve eye diameter of $1.2 \mathrm{~mm}$ and $3 \mathrm{~mm}$ to obtain a recyclate that served as a filler added to the matrix of the composite. Fig. 2 shows recycle after sieving on a sieve with a diameter of $1.2 \mathrm{~mm}$ and $3 \mathrm{~mm}$. Preparation of a recyclate of such granulation is a quite complex process and strongly affecting the environment - a large amount of highly irritating dust is formed. Therefore, the process of preparing the material for the study required appropriate equipment and protections. In the laboratory of Department of Engineering Sciences of the Gdynia Maritime University, a concept was developed and a stand for grinding plastics was obtained [7].

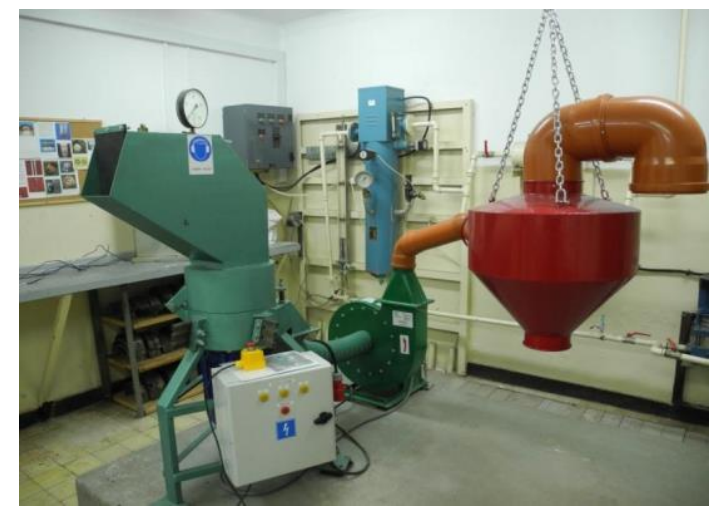

Fig. 1. Stand for processing composite materials acquired by the Gdynia Maritime University
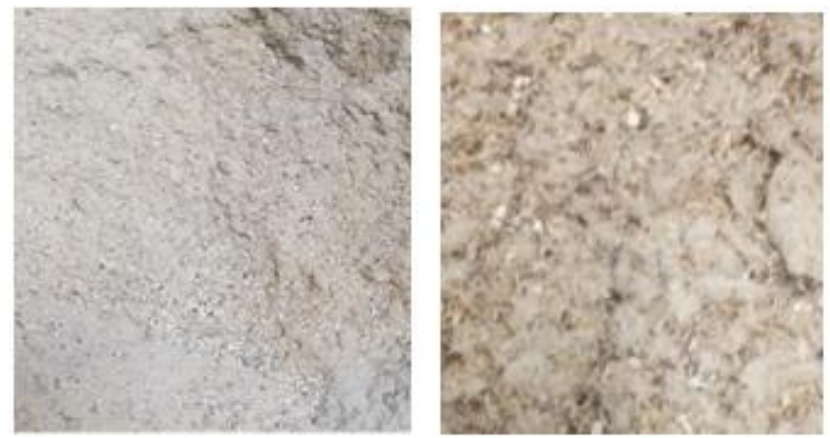

Fig. 2. Material sieved on a sieve, granulation: $1-1.2 \mathrm{~mm}, 2-3.0 \mathrm{~mm}$ 


\section{MANUFACTURE TECHNOLOGIES FOR COMPOSITES}

An important role in the process of making composites is the selection of appropriate technology, guaranteeing the product with the best performance, good repeatability and taking into account economic considerations - profitable. The cheapest and most frequently used technology for the production of polymer composites is the contact lamination method. Currently, more and more often automated technologies for the production of polymer composites are used, such as vacuum bag and infusion, which guarantee better quality and repeatability of products $[2,6]$.

In order to make composites with polyester-glass recyclate, a mat with random fiber direction was used as reinforcement. The advantage of using this type of reinforcement is comparable properties in different directions. The basis was Polimal 1094-AWTP resin. Polimal 1094 AWTP-1 is a structural resin, medium-elastic, orthophtalic, accelerated, with low styrene emission and a colored hardening index system [14]. Tab. 2 shows the properties of the selected polyester resin.

Tab. 1. Properties of glass mat used in the production process [3]

\begin{tabular}{|c|c|c|c|}
\hline Density & Strength of material, Rm & Young modulus, E & Elongation after tearing \\
\hline $\mathrm{kg} / \mathrm{m} 3$ & $\mathrm{MPa}$ & $\mathrm{GPa}$ & $\%$ \\
\hline 2550 & 2900 & 73.5 & 3.37 \\
\hline
\end{tabular}

Tab. 2. Properties of Polimal 1094 AWTP polyester resin [14]

\begin{tabular}{|c|c|c|}
\hline Test parameter / standard & Unit & Value \\
\hline Viscosity, at 20s-1 (ISO3219), $23^{\circ} \mathrm{C}$ & $\mathrm{mPa}$ s & $\mathbf{3 0 0 - 4 5 0}$ \\
\hline $\begin{array}{c}\text { Gel time, at } 25^{\circ} \mathrm{C} \\
\text { by ISO } 2535\end{array}$ & minut & $\mathbf{1 9 - 2 6}$ \\
\hline $\begin{array}{c}\text { Flexural strength, min } \\
\text { by ISO } 178\end{array}$ & $\mathrm{MPa}$ & $\mathbf{1 1 0}$ \\
\hline $\begin{array}{c}\text { Tensile strength, min } \\
\text { by ISO 527-2 }\end{array}$ & $\mathrm{MPa}$ & $\mathbf{4 3 0 0}$ \\
\hline $\begin{array}{c}\text { Young modulus } \\
\text { by ISO 527 }\end{array}$ & $\mathrm{MPa}$ & $\mathbf{2}$ \\
\hline $\begin{array}{c}\text { Tension extension } \\
\text { by ISO 527 }\end{array}$ & ${ }^{\circ} \mathrm{C}$ & $\mathbf{6 3}$ \\
\hline $\begin{array}{c}\text { Thermal resistance (HDT) } \\
\text { by ISO 75 }\end{array}$ & & \\
\hline
\end{tabular}

\section{Manual lamination - hand lay-up}

The simplest method of forming composite elements is manual lamination. It involves laying the reinforcement in the form (subsequent values of the glass mat) 
and saturating it with resin using rollers, brushes, etc. Depending on the amount of hardener and accelerator after saturating the resin gels, crosslinks and then cures. Since the resin is applied to the mold in a liquid state at the same time as the reinforcement, this method is called the 'wet' lamination method.

In the manual method, fibers in the form of mats and fabrics or a combination of both materials are laid in the form of wide (1-2.5 mb) reinforcement strips unwound from the roll. The efficiency of laminate production in this technology varies from $4 \mathrm{~kg} /$ working hour of the product with complicated and small details up to $20 \mathrm{~kg} /$ working hour with large and simple elements [13].

In order to make a composite with polyester-glass recyclate, it was necessary to prepare the form using a separator in the form of, for example, wax. The next step was verification of the percentage of resin (64\%), mat (26\%) and recyclate $(10 \%)$, in order to filter the entire mat and obtain the material with the best properties (10 layers of mat). After lamination attempts, the above \% content proved to be the most advantageous. In the case of manual lamination, it is difficult to obtain a material with a higher reinforcement content in relation to the matrix. The recyclate was mixed with the resin to obtain a material with comparable properties, and then the hardener was added.

The manual laminating method requires proper verification of resin curing time, an appropriate number of trials should be carried out with different content of hardener and accelerator. When adjusting to the instructions $(1 \% / \mathrm{kg})$, the average gel time is 19-26 minutes, filtering the small form is not a problem. In a situation where we deal with a larger element, it is worth considering the amount of hardener. The advantage of this method is the gelation and crosslinking time itself, which can be lengthened at will. In addition, the tooling itself is not demanding. In the production of recycled composites, there were no major problems in the production of this type of material, for example combining a recycled resin, as well as filtering the glass mat.

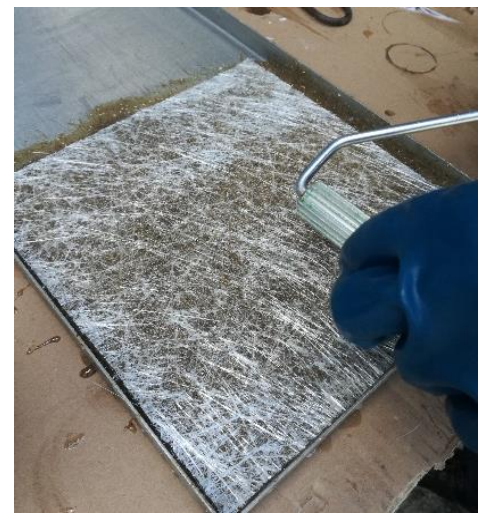

Fig. 3. Composite with recycled polyester-glass during manual lamination 


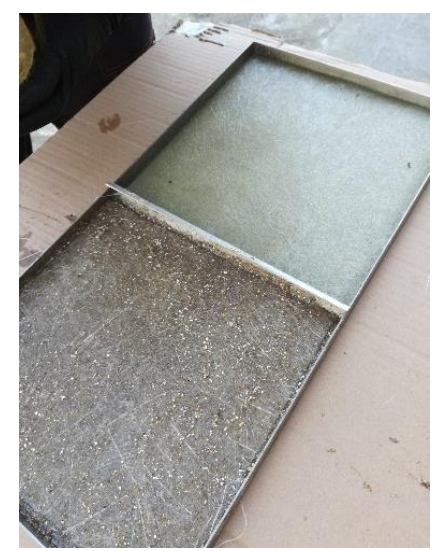

Fig. 4. Composite after manual lamination

\section{Vacuum Bagging method}

Using the manual laminating method, defects can not be avoided, such as the air pore between the laminate layers and in the laminate itself. We obtain a better effect by removing air before the resin cures. This process is called deaeration. The use of negative pressure allows us to create a pressure which, by balancing the stress of the reinforcement fabric, allows the subsequent layers of the laminate to adhere better to each other and the mold, as well as getting rid of the air. In addition, if we apply a vacuum before the resin begins to gel, we can suck off excess non-crosslinked resin, thanks to which we will obtain a material with a higher content of reinforcement in the composite, which is tantamount to an increase in strength properties. The vacuum bag method 'forgives' also shortcomings in the lamination, such as inaccurate filtration of subsequent layers [13].

With the vacuum bag method, the same is done as with manual lamination, but before we put the gelcoat, we should cover the surface with butyl tape. After the element is laminated, a series of activities are performed, the separating foil is applied to the laminate, and then the draining fabric, so-called Breather (fig. 5). The vacuum system is then connected until it cures.

The percentage of reinforcement in relation to the carcass, with the vacuum bag method depends largely on the amount of hardener. It affects the time of gelation, crosslinking and subsequent curing. The vacuum bag method, due to the use of manual lamination in the process, seems to be equally beneficial considering the addition of polyester-glass recyclate. Additionally, thanks to the use of a vacuum, it is possible to obtain relatively better strength properties. With the vacuum bag method, in addition to the standard equipment for manual lamination, first of all a vacuum pump is required, besides a separating film, Breather drainage foil, vacuum foil, butyl tape, etc. 


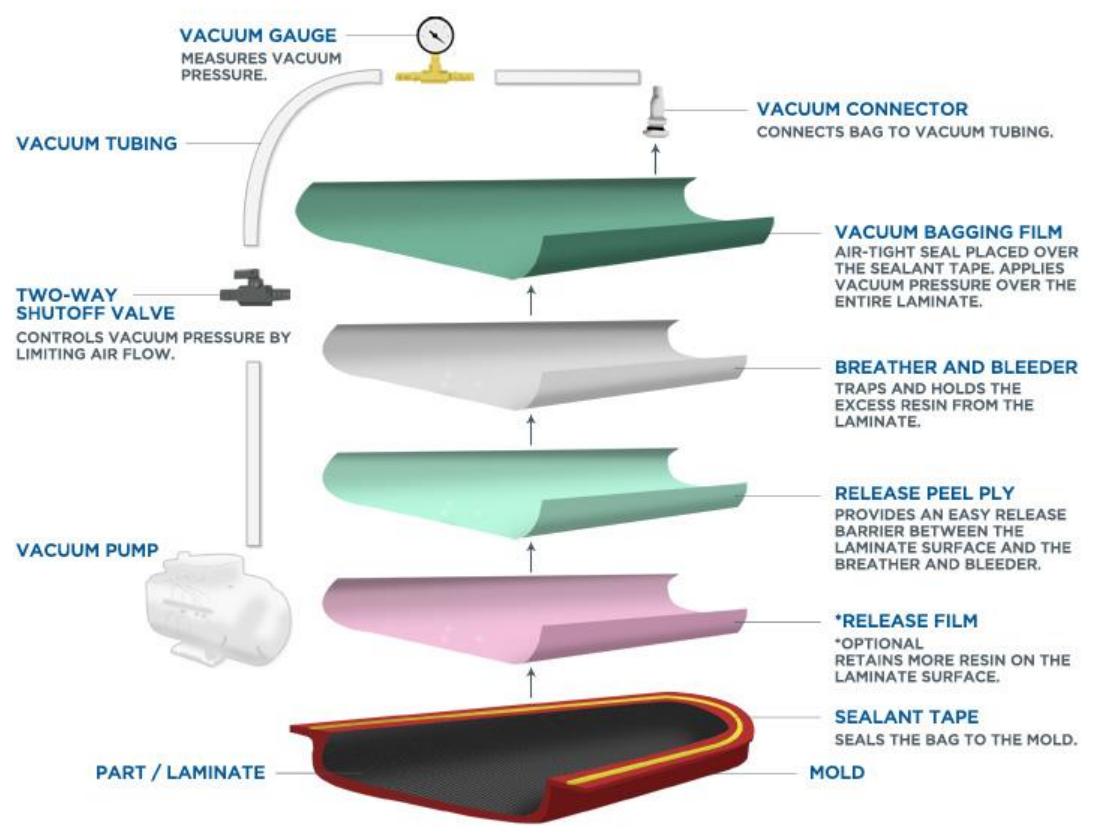

Fig. 5. Scheme of vacuum bag technology [13]

Initial research on the use of the vacuum bag method for the production of recycled composites with the same polyester resin and glass mat [resin (64\%), mat (26\%) and recyclate (10\%)], shows a slight increase in strength properties (fig. 6), in the range of approx. $4.5 \%$. In the case of composites without recyclate, an increase in properties by approx. $13 \%$ was obtained. The time of crosslinking has a huge in-fluence in the application of this method for the production of recycled composites - the longer it is, the more likely it is to obtain a composite with a lower percentage of the matrix - more reinforcement. This allows you to obtain a material with better properties.

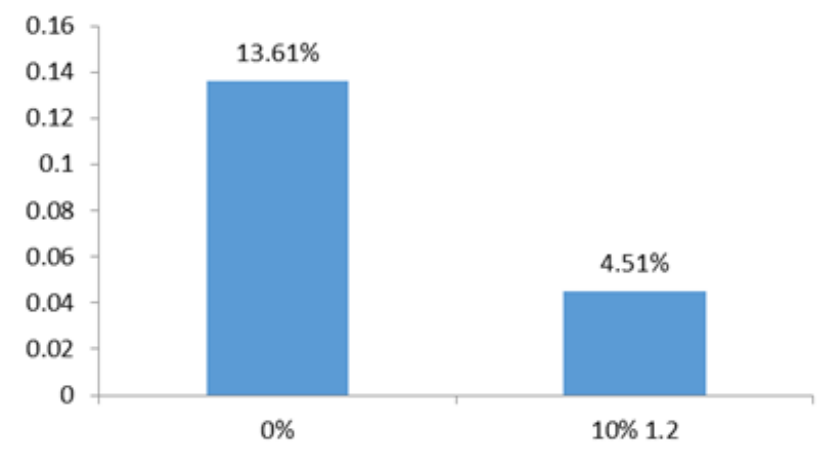

Fig. 6. Percentage increase in strength properties of composites without recyclate $(0 \%)$ and with $10 \%$ content $(10 \% 1.2)$ made by the vacuum bag method in relation to manual lamination 


\section{Vacuum Infusion method}

Vacuum infusion is gaining increasing popularity, because it allows to obtain very high strength parameters of the composite (reinforcement content 50-60\%). This method is used in the manufacture of e.g. hulls of large sailing yachts, wind tur-bine blades. It is based on the arrangement of the next layers of reinforcement on the form covered with a separator, taped with butyl tape. In contrast to the vacuum bag method, a special mesh is placed between the separating and draining fabric, thanks to which the resin evenly spreads the mat layers. After preparing all the layers, unfolding the installation, sealing the bag and pumping out air, the resin is injected. As with the vacuum bag method, the amount of hardener is very important so that the entire reinforcement layer can be filtered [13].

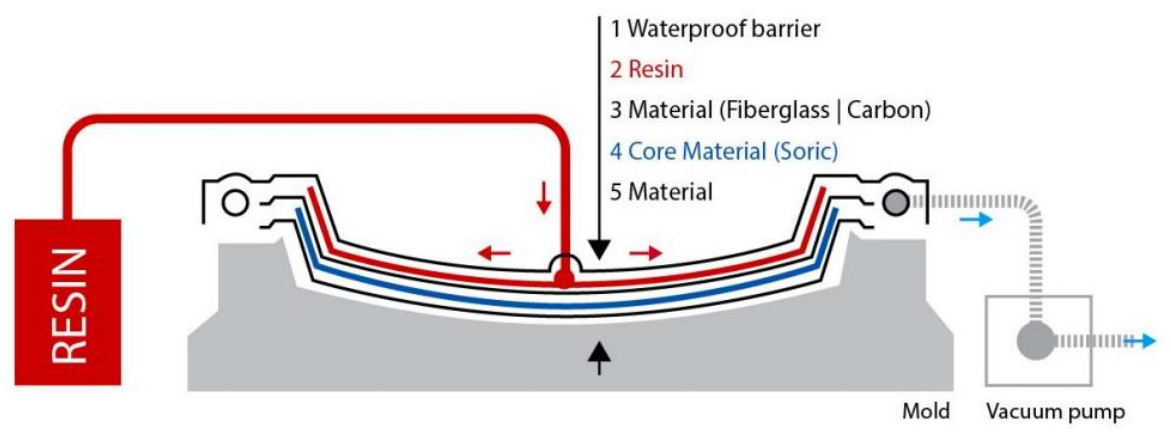

Fig. 7. Scheme of Vacuum Infusion [11]

The biggest advantage of vacuum infusion is to increase the share of reinforcement, remove excess resin, eliminate air pores and voids, as well as reduce the emission of styrene. The infusion technology as well as the vacuum bag method allow for the removal of shortcomings in manual lamination [10]. One of the disadvantages of the infusion is leaving areas not included in the element, e.g. when the gelling time is not properly selected and the resin will mesh before the whole of the area is filtered or drained and the possibility of discharging air from it is closed $[5,9]$. Therefore, experience is required to make composites with this technology. In addition, if you want to make composites with polyester and glass recycled problems may arise, reinforcement for recycling may turn out to be a kind of filter. It is also worth mentioning the requirements of this method in terms of instrumentation and materials, as in the case of the vacuum bag method. 


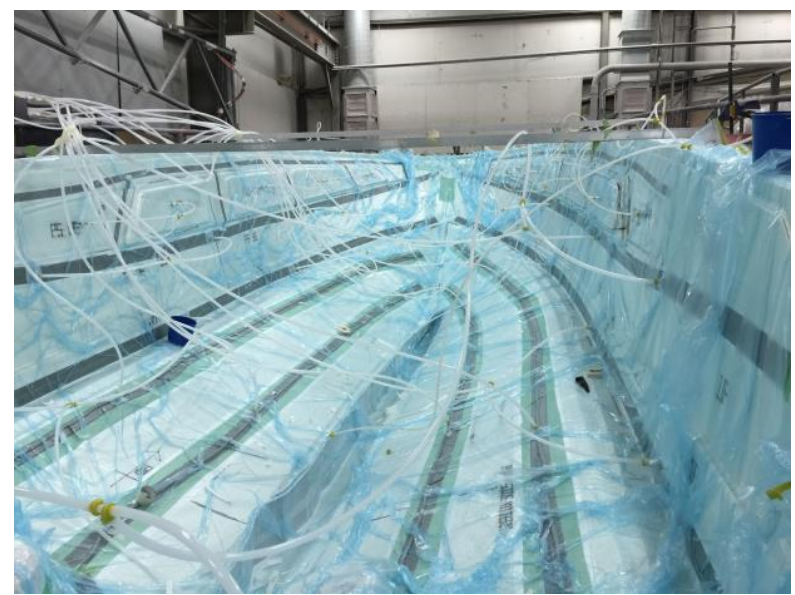

Fig. 8. Cruiser yacht during Vacuum Infusion [12]

\section{CONCLUSIONS}

The condition for obtaining a composite with the best strength properties is the proper connection with one another, by means of a matrix, of reinforcement in the production process. The greater the volume ratio of the reinforcement in the composite, the better the strength properties of the material. This is one of the basic criteria when assessing the suitability of technology for the production of polymer composites, of which there are a lot - from technologies completely dependent on the human factor (manual) to almost completely independent (automated) [13].

Manual lamination using the contact method is a technology that is not very demanding when it comes to materials and tooling, and does not require experience. A glass-polyester recyclate as a material combined with a resin, does not affect the manufacturing process, it is not a problem. By insight into imperfections in the manufacturing process, such as air bubbles, as well as reinforcement content in relation to the matrix, strength properties leave much to be desired.

In the vacuum bag method, appropriate equipment and materials are already necessary, as well as experience in making composites using this method. The use of polyester-glass recyclate, as in the case of laminating, has no effect on the production. Thanks to the use of a vacuum bag and suction of excess resin, it is possible to obtain a composite with much better strength parameters. However, knowledge about the amount of hardener is very important here to optimize the gelation time. Preliminary studies have shown a slight increase in strength properties for recycled composites, but with optimized crosslinking time, satisfactory results could be obtained. 
Infusion is a method that is getting more and more popular in Poland and around the world. Thanks to this method, a product with better quality and lower mass is gained, and the technology itself is clean and environmentally friendly, by reducing the emission of styrene. As in the case of the vacuum bag method, the tooling and materials play a significant role, experience is not necessarily. Once properly developed technology, i.e. the right amount of hardener and time of gelation, to the size of the element, can be used for a long time. Unfortunately, it is likely that the production of polyester-glass recycled composites with granulation of $1.2 \mathrm{~mm}$ and $3 \mathrm{~mm}$ may be impossible, by the behavior of the glass fiber like a filter.

Considering the technologies analyzed in this paper for the production of polyester-glass recycled composites, the vacuum bag method seems to be the most advantageous. It is successfully used in the automotive industry for the production of yachts and motorboats. The addition of polyester and glass recyclate for the production of new composites can have a positive impact on the recycling of composites in Poland and around the world. The article is a prelude to research on composite materials with the addition of polyester-glass waste.

\section{REFERENCES}

[1] Dvorak R., Kosior E., Hopewell P., Plastics recycling: challenges and opportunities, 'Philosophical Transactions of The Royal Society', August 2009, pp. 2115-2126.

[2] Govignon Q., Bickerton S., Morris J., Kelly P.A., Full field monitoring of the resin flow and laminate properties during the resin infusion process, 'Composites. Part A', 2008, No. 39, pp. 1412-1426.

[3] Hyla I., Śleziona J., Kompozyty. Elementy mechaniki i projektowania, Publ. Silesian University of Technology, Gliwice 2004 [Composites. Elements of mechanics and design — available in Polish].

[4] Kowalska E., Wielgosz Z., Bartczak T., Utylizacja odpadów laminatów poliestrowo-szklanych, 'Polimery', 2002, Vol. 47, No. 2, pp. 110-116 [Waste disposal of polyester-glass laminates available in Polish].

[5] Lunn P., Tooling materiale ideal for resin infusion, 'Reinforced Plastics', 2004, Vol. 48, No. 8, pp. 345-368.

[6] Myalski J., Określenie warunków infiltracji w infuzyjnej metodzie wytwarzania laminatów poliestrowo-szklanych, 'Kompozyty', 2009, Vol. 9, No. 2, pp. 138-143 [Determination of infiltration conditions in the infusion method of producing polyester-glass laminates — available in Polish].

[7] Panasiuk K., Hajdukiewicz G., Production of composites with added waste polyester-glass with their initial mechanical properties, 'Scientific Journals of the Maritime University of Szczecin', 2017, Vol. 52, No. 124, pp. 30-36.

[8] Pickering S. J., Recycling technologies for thermoset composite materials - current status, 'Composites. Part A: Applied Science and Manufacturing', 2006, Vol. 37, No. 8, pp. 1206-1215.

[9] Sevostianov I. B., Verijenko U. E., Von Klemperer C. J., Chevallereau B., Mathematical model of stress formation during vacuum resin infusion process, 'Composites. Part B', Vol. 30, No. 5, pp. 513-521. 
[10] Wiliams C. D., Grove S. M., Summerscales J., The compression response of fibre-reinforced plastic plates during manufacture by the resin infusion under flexible tooling metod, 'Composites. Part A', 1998, Vol. 29, No. 1-2, pp. 111-114.

[11] http://liteboat.fr/technology/ [access 29.05.2018].

[12] http://vectorply.com/infusion-success-starts-with-r2o/ [access 29.05.2018].

[13] http://www.baltazarkompozyty.pl/index.php?option=com_content\&view=article\&id=224:technologie-wytwarzania-kompozytow-polimerowych-cz-1\&catid=15\&Itemid=46 [access 27.04.2018].

[14] http://www.ciechzywice.pl/pl/produkty/chemia-organiczna/zywice/zywice-poliestrowenienasycone [access 27.04.2018].

[15] https://archiwum.mos.gov.pl/g2/big/2013_03/59197ee6f23ffae7686d24b56e7687bd.pdf [access 27.04.2018].

\section{ANALIZA TECHNOLOGII WYTWARZANIAKOMPOZYTÓW Z RECYKLATEM POLIESTROWO-SZKLANYM}

\section{STRESZCZENIE}

Celem artykułu było przedstawienie wybranych metod wytwarzania kompozytów warstwowych $\mathrm{z}$ dodatkiem recyklatu poliestrowo-szklanego. Recyklat poliestrowo-szklany został otrzymany z oryginalnego materiału kompozytowego, z którego wykonany jest kadłub statku wyprodukowanego w Polsce w latach osiemdziesiątych XX wieku. Przedstawiono technologię przetwarzania odpadów poliestrowo-szklanych w celu otrzymania recyklatu. Opisano kolejno metody laminowania ręcznego, metodą worka próżniowego oraz infuzji próżniowej na podstawie własnych badań. Scharakteryzowano zalety oraz wady poszczególnych technologii pod kątem kompozytów z recyklatem poliestrowo-szklanym. Z opisanych i zweryfikowanych technologii najkorzystniejsza dla kompozytów z recyklatem wydaje się metoda worka próżniowego.

Słowa kluczowe:

kompozyty, laminowanie ręczne, metoda worka próżniowego, infuzja próżniowa.

Article history

Received: $\quad 04.06 .2018$

Reviewed: 20.09 .2018

Revised: $\quad 28.09 .2018$

Accepted: $\quad 29.09 .2018$ 